\title{
Linking projects with value in credits to validate realisation of professional internship, the protocol in the FIAD - UABC.
}

\author{
J. L. J. Sánchez González*, J. I. Aguilar Duque**, J. Salinas Coronado**, G. Amaya \\ Parra**, V. M. Juárez Luna**, J. A. Michel Macarty**，J. I. Nieto Hipólito** \\ Universidad Autónoma de Baja California, Mexico \\ Facultad de Ingeniería, Arquitectura y Diseño
}

\begin{abstract}
This work presents the curricular professional internship Protocol, within the framework of linking projects with value in credits (PVVC), in the Faculty of Engineering, Architecture and Design (FIAD) of the Autonomous University of Baja California (UABC). (Initials come from the names in Spanish). This Protocol defines the mechanism to start, to register and to follow-up to fruition the curricular professional internship (PP's). The benefits of this Protocol include but are not limited to standardization of documents and deadlines of the procedures. It regulates the actions of supervision of the activities of the students at the receivers' premises. It is obligatory to write a report of activities in a format of publication. It involves academics in a way that promotes interaction with the productive sector for a possibility of linking academic at the same time or after the realization of this student bonding. In addition to that we have implemented a tool that facilitates the available formats, control, monitoring, broadcasting and Bank of storage of the generated PVVC's and their reporting.
\end{abstract}

Keywords: Internship; linking; projects; protocol; FIAD-UABC; PVVC.

\section{Introduction}

In the FIAD, all educational programs require the realisation of a professional internship (PP's) as a mandatory curricular element; a number of credits are assigned to it, and therefore is a degree requirement. On the other hand, linking projects with value in credits are defined in the plans of study, as a container for a number of actions, forms of teaching - learning and accreditation, resulting in the operation of an educational scheme within the social or productive sector. In this way students can obtain credits with the activities carried out in the companies (public or private), as well as social service or professional internship.

Particularly in the Industrial Engineering education program (PE), was defined that mandatorily students carried out stays in business, and to frame these activities in the PVVC's would be very convenient for companies, students and teachers. As a professor is responsible for defining, monitoring and evaluating this mode of teaching-learning, the need to organize and store the substantiating documents for an appraisal, certification and/or PE monitor, was addressed in different ways. The experience gained during several semesters, has matured into the Protocol which is presented below, and has already spread to the other PE's of the FIAD.

\section{Methods}

The educational model of the UABC, contemplates the choice of modes of learning, as an alternative to traditional teaching, so that the student develops their intellectual potential and abilities, through learning experiences that are creative and innovative; at the same time obtaining credit as part of their graduation requirement. The curriculum is structured by stages, these being: basic stage (knowledge inter or multidisciplinary), disciplinary stage (or knowledge) and terminal stage (applications knowledge). It is in this last stage where the student is focused on increasing practical 
work and their participation in the occupational field. All University programs have the requirement of 300 credits (cr) minimum and 350 credits maximum, there bare compulsory subjects around $70 \%$, optional subjects and professional internships.

In the Educational Status of the UABC, chapter ninth of patterns of learning and earning credits, mark in its article 155 subsection IX brand linkage projects with value in credits as one of these modalities, where each respective curriculum establishes the characteristics and scope of them.

Table 1. Modalities obtain credit for the UABC, Educational Status UABC

I. Mandatory learning units,

II. Learning units optional ,

III. Other elective courses ,

IV. Independent study,

V. Teaching assistantships,

VI. Research assistantships

VII. Investigative exercise,

VIII. Support outreach and liaison,

IX. Linkage project value credits (PVVC),

X. Projects by degree,

XI. Artistic and cultural activities,

XII. Sport activities,

XIII. Social community service associate to the curriculum

XIV. Professional social service, associated with the curriculum

XV. Professional practices associated with the curriculum

XVI. University entrepreneurs program

IVII. Activities for training in securities

VIII. Intersemestrales school courses or other periods

XIX. Student exchange

$\mathrm{XX}$. Foreign language, and

XXI. The cases of the University established

UABC has recently developed guidelines and tools of control, within these new guidelines, flexibility for implementation at any time of the year, and a variability of stay length are allowed. Linkage projects (PVVC) are defined as follows:

PVVCs are optional projects (not compulsory to get a title), they are developed in coordination between the University and social or industrial sectors in the community. They are a learning experiences supervised by university faculty and external professionals and the linkage council of every school. This projects have the purpose of application and generation of knowledge, and problems solutions, either through research activities or professional services, in order to enhance educational outcomes and learning goals. (Title V, chapter 9, article 158, Educational Status, UABC).

This PVVCs are containers, that can encapsulate, compulsory subjects, optional subjects, modalities of learning (research or teaching internships, 
independent studies, social service, etc), taking in consideration regulation of each program.

Table 2. PVVCs Level.

\section{LEVEL 1}

$\checkmark$ Two months and 160 hours

$\checkmark$ Two learning units (maximum up to 6 credits each) and PVVC (2 credits) itself.

$\checkmark$ Being up to 14 credits in total to assign.

\section{LEVEL 2}

$\checkmark$ Three months and 240 hours.

$\checkmark$ Two learning units (up to 6 maximum credits each) and a mode of learning (professional practice, 15 credits or other form, 6 credits) and PVVC (2 credits).

$\checkmark \quad$ Being up to 29 credits in total to assign.

\section{LEVEL 3}

$\checkmark$ Four months and 360 hours

$\checkmark$ To most three learning units (up to 6 credits maximum each) and maximum three modes of learning (eg: professional practice, 15 credits and investigative exercise, 6 credits) and PVVC (2 credits).

\section{$\checkmark$ Being up to 41 credits total for assigning and do not exceed five shares in total.}

The Protocol FIAD - UABC of linking projects with value in credits (PVVC) is a guideline recommended to students for registration, execution, control, protection, evaluation and request for validation of the associated PP's.

\section{Protocol FIAD - UABC}

Below the objective, the procedure of execution of the PVVC's and the application of validation for the PP's, are defined.

\section{Objective}

The student in conjunction with FIAD-UABC and a company define a technical project that reinforces the theoretical knowledge - acquired during their academic preparation. The company can be public, private or agency. The PVVC scheme helps us to validate the request for release of the internship.

\section{Procedure}

\section{II.a Begining:}

- Find a company in which the linking project (PVVC) could be carried out.

- Request presentation letter to the Coordinator of linking FIAD sending by email the following information: 
- Student data: a) full name, b) registration number and c) career.

- Company data: d) full name of the contact, e) his profession title (Eng., Lic., etc.), f) position d) full name of the company

\section{II.b Registration:}

- The technical project is described in a document named Colaboration Agreement (Convenio de Colaboración in Spanish) signed by all parts involved. This document must be delivered before a deadline, defined every semester by the FIAD administration. There is a format that must be followed.

\section{II.c Follow up:}

- Request permission to the company to make a supervision visit. The Tutor responsible must make this visit within the 1st month of the PVVC period.

- Weekly attendance (face-to-face or virtual) with its tutor responsible at UABC is compulsory.

- Delivery of partial reports to the Tutor responsible UABC, with the time frame agreed.

- Register attendance, on the sheet control of PVVC's on the hosted site. (Access from your mail account in UABC).

- Submit partial reports to the hosted site.

\section{II.d Validation:}

- A final report must be delivered for review the responsible tutor UABC (1 week before the end of the PVVC period). The Tutor responsible for UABC supports the presentation of the PVVC final version either in the ordinary or extraordinary Colloquium pf PVVC.

- One week before the Colloquium, the student must deliver, in paper and electronic, the following six documents (pdf):

1. Final project report

2. Responsible tutor participation letter ( emitted by company)

3. Collaboration Agreement

4. Grade letter emitted by company

5. Evidence of surveys (employers and students).

\section{II.e Evaluation:}

- The project must be presented in person before a group of evaluators from the corresponding Academy, during the Colloquium of PVVC. This committee assigns a grade according with results presented. Final grade will be the average of this mark and the one from Company.

\section{Validation of professional internship:}

- The grade obtained by the student by a PVVC is enough to request for release of the professional internship. 


\section{Results and Discussion}

In the period from 2011 to 2014, the Faculty of Engineering, Architecture and Design (FIAD-UABC) registered and evaluated 346 PVVC, being: 40 made with Public Sector, 19 made with the Social Sector and 287 made with the private Sector (mainly in the city of Ensenada, Baja California, Mexico). Whereas the results by PE of the faculty, are: 282 from Industrial Engineering, 17 of Electronic Eng., 17 Civil Eng., 22 from Computer Eng., 4 of Bioengineering, and 4 from Architecture.

Table 3. 2011 to 2014 FIAD's PVVC Resum, by period and PE of the FIAD.

\begin{tabular}{|cc}
\hline Sector's Impact & \\
Public & 40 \\
Social & 19 \\
Private & 287 \\
\hline FIAD's PVVC & \\
(2011 to 2014) & 346
\end{tabular}

Figure 1. Results of PVVC for the period from 2011 to 2014 by Sector's impact on the city of Ensenada, Baja California, Mexico.

\section{FIAD’s PVVC (2011 to 2014) by Sectors Impact}

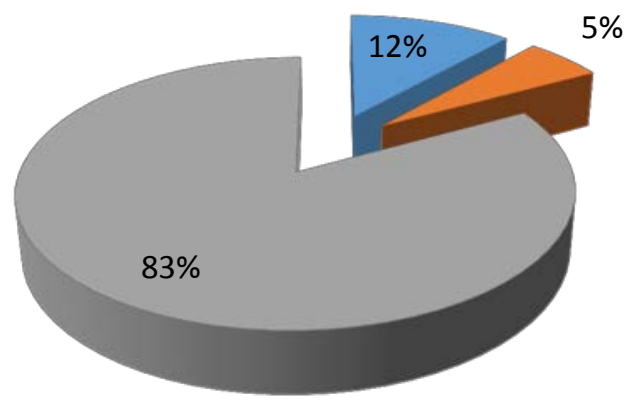

$\square$ Public 40

$\square$ Social 19

$\square$ Private 287

Table 4. 2011 to 2014 FIAD’s PVVC Resum, by period and Sector's impact.

$\begin{array}{cc}\text { Educational Program (PE) } \\ \text { Industrial } & 282 \\ \text { Electronic } & 17 \\ \text { Civil } & 17 \\ \text { Computer } & 22 \\ \text { Bioengineering } & 4 \\ \text { Architecture } & 4 \\ \text { FIAD's PVVC } & \\ \text { (2011 to 2014) } & 346\end{array}$


Figure 2. Results of PVVC for the period from 2011 to 2014 a by PE of the FIAD.

\section{FIAD’s PVVC (2011 to 2014) by Educational Program}

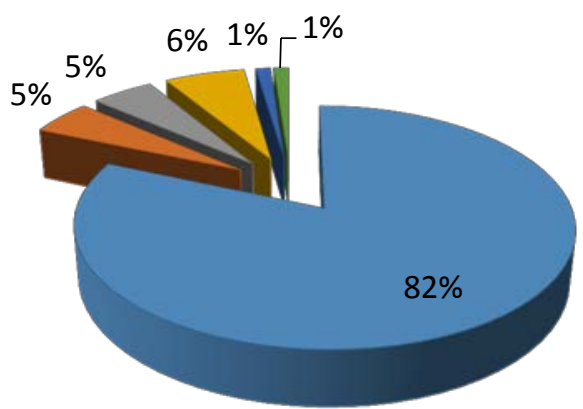

$\square$ Industrial 282

$\square$ Electronic 17

$\square$ Civil 17

$\square$ Computer 22

• Bioengineering 4

$\square$ Architecture 4

\section{Conclusions}

The implementation of this Protocol FIAD - UABC has been very effective to improve the transit of the students at the Terminal stage, to provide clear mechanisms for mapping, monitoring, evaluation and validation of professional internships, within the framework of the PVVC's. 2012 and 2013 cycles, other PE's of the FIAD, in addition to the Industrial engineering students have been incorporated and he is expected for 2015, increase the number of students who register a PVVC, so that standardize this Protocol.

The evaluation of the results of these PVVC's, is carried out within the framework of a colloquium FIAD - UABC's PVVC, that in addition to the virtual library provides a valuable opportunity for the dissemination of the interaction of the FIAD with the productive sector of the city. Also it has a memory that feeds and guides future actions of bonding, so that professional practices, are more profitable, the productive sector, for both students, teachers, the Faculty and University.

It should be mentioned that it is important to consider activities that help a recognition of national and international competition and a validation of their expertis in graduates, which is why we have made efforts by our government with the governments of Canada and the United States, professional practices and the application model of PVVC's could help in this regard. It is noteworthy that Mexico and the United States signed, on March 16, 2015, the Memorandum of Understanding for the Creation of Professional Practice. A memorandum of understanding for the creation of the Internship Program that seeks to expand academic exchanges and opportunities for professional practices for Mexican and American students, college students and recent graduates. This will increase opportunities for educational exchange with the aim of developing the regional workforce to position North America as a more competitive and dynamic region in the world. 


\section{References}

Universidad Autónoma de Baja California (2006). Estatuto Escolar de la Universidad Autónoma de Baja California, Ed. Gaceta Universitaria, 170, 38-39.

http://sriagral.uabc.mx/Externos/AbogadoGeneral/index_htm_files/ESTATUTOESC OLARUABC(REFORMASDEOCTUBRE2014).pdf

Universidad Autónoma de Baja California (2013). Modelo Educativo de la UABC, Cuamea Velázquez, F.

Facultad de Ingeniería, Arquitectura y Diseño - Universidad Autónoma de Baja California (2015). 3er Informe de Actividades 2014-1 y 2014-2, Nieto Hipólito, J. I.

http://fiad.ens.uabc.mx/index.php/formacionprofesional/vinculacionextencion

Facultad de Ingeniería, Arquitectura y Diseño - Universidad Autónoma de Baja California (2012). Los proyectos de vinculación con valor con crédito validan la realización de la prácticas profesionales, el protocolo en la FIAD - UABC, Ed. ANUIES - UABC, Sánchez González, J. L. J., Nieto Hipólito, J. I.

http://saladeprensa.sre.gob.mx/index.php/es/comunicados/5771-141

Secretaria de Relaciones Exteriores (2015). Comunicado firma de memorándum de entendimiento para la creación de prácticas profesionales México - Estados Unidos, Gobierno de México. 